\title{
Experimental Study of Bio-Security of Functionalized Single-Walled and Multi- Walled Carbon Nanotubes
}

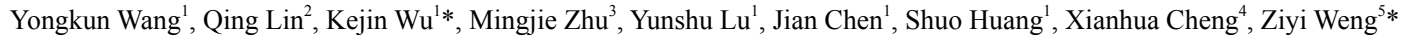 \\ Departments of ${ }^{1}$ General Surgery, ${ }^{2}$ Oncology, ${ }^{3}$ Pathology and ${ }^{5}$ Colorectal Surgery, Xinhua hospital, Shanghai Jiaotong University School of \\ Medicine, Shanghai 200092, China. \\ ${ }^{1}$ Department of General Surgery, Xinhua hospital, Shanghai Jiaotong University School of Medicine, Shanghai 200092, China. \\ ${ }^{4}$ College of Mechanical and Engineering, Shanghai Jiaotong University, Shanghai 200092, China .The first two authors contribute equally. \\ ${ }^{5}$ Department of Colorectal Surgery, Xinhua hospital, Shanghai Jiaotong University School of Medicine, Shanghai 200092, China. \\ *Corresponding author:ziyiweng@163.com (Ziyi Weng) or kejinwu1128@163.com (Kejin Wu)
}

Abstract

In this study, the biological effects of functionalized carbon nanotubes (CNTs) were investigated on cell morphology, proliferation, apoptosis, tissue pathology and blood test in vivo \& in vitro. The functionalized CNTs had good biocompatibility at lower concentrations, and the functionalized single-walled carbon nanotubes(SWCNTs) perform in the early period in the animal body and multi-walled carbon nanotubes(MWCNTs) mainly in the late. The results show successful functional groups and no change in toxicity in functional samples compared with the primary sample, and there is a safety dosage on the normal cells and tissue. In subsequent studies, antitumoral investigations of modified samples will be evaluated.

Keywords: functionalized carbon nanotubes, bio-security, pathology

Citation: Y. Wang, et al. Experimental study of the bio-security of functionalized single-walled and multi-walled carbon nanotubes. Nano Biomed. Eng. 2011, 3(4), 249-255. DOI: 10.5101/nbe.v3i4.p249-255.

\section{Introduction}

The materials below nano-scale $(0.1-100 \mathrm{~nm})$ have a special nature, so nano-materials have broad application prospects in almost all areas. Carbon nanotubes include of single-walled carbon nanotubes (SWCNTs) and multi-walled carbon nanotubes (MWCNTs). Carbon nanotubes have been attracting increasing attention from chemists and scientists owing to their electronic, mechanical, optical, and chemical characteristics [1-3]. Biomedical applications for CNTs are being investigated actively because of their useful combination of size and physicochemical properties [4-8]. In patients with cancer, MWNTs have potential roles in delivering pharmacologic agents, as diagnostic imaging agents, DNA, silent interfering RNA, oligonucleotides, and proteins to detect or treat cancerous cells [9-11]. The application of functionalized CNTs as new nanovectors for drug delivery was apparent immediately after the first demonstration of the capacity of this material to penetrate into cells. CNTs can be used to deliver their cargoes to cells and organs. In recent years, chemical functionalized of CNTs has become more interesting because it allows modification of the nanotube surface for subsequent alignment. These surface modifications play an important

Nano Biomed. Eng. 2011, 3(4), 249-255 role for application of nanotubes in composite sensors and many other fields. The chemical modifications of CNTs have been well summarized in several published review articles. In order to bind biological macromolecules onto CNTs, the surface is generally required to be oxidated by carboxyl or hydroxyl groups. On the one hand, the functionalized CNTs combine proteins or DNA by covalent binding or a combination of electrostatic interactions, on the other hand, increase its hydrophilic, making it easier to disperse in solution. In this study, with a mixed acid purification, the CNTs surface was rich in hydroxyl and carboxyl functional groups to make it functional. In this study, we investigated the biological effects of functionalized CNTs on normal rat liver, kidney and nerve cells proliferation at the cellular level and normal SD rat heart, liver, kidney structure and function at the animal level, to provide experimental data for the evaluation of CNTs in cell and animal bio-safety and the CNTs using in bio-medical treatment.

\section{Materials and Methods}

\subsection{Test materials and reagents}

DMEM and RPMI 1640 medium, fetal bovine Odhast 249 
serum(FBS), $0.25 \%$ trypsin-EDTA mixture(containing $0.25 \%$ trypsin $\mathrm{w} / \mathrm{v}$ and $0.02 \%$ EDTA w/v), and antibiotics solution(containing $1000 \mathrm{U} \mathrm{mL}^{-1}$ penicillin and $10 \mathrm{mg}$ $\mathrm{mL}^{-1}$ streptomycin) were purchased from Gibco.

\subsection{Preparation of test samples}

Functionalized SWCNTs and MWCNTs, purified by mixed acid to make it rich in hydroxyl and carboxyl functional groups on the surface, were provided by the College of Mechanical and Engineering, Shanghai Jiao Tong University.

\subsection{Toxicity in vitro}

\subsubsection{Cell culture}

Normal rat liver cell BRL-3A, kidney cell NRK, Schwann cell RSC96 were purchased from the Shanghai Cell Bank of Chinese Academy of Sciences(Shanghai, China). BRL-3A cell was maintained in RPM11640 essential medium supplemented with $10 \% \mathrm{FBS} \mathrm{v} / \mathrm{v}$ and $\mathrm{P} / \mathrm{S}$, and incubated at $37^{\circ} \mathrm{C}$ under $5 \% \mathrm{CO}_{2}$. Cells were subcultured every 3 to 4 days. NRK and RSC96 cells were maintained under DMEM medium with the same condition. When the cells were fully adherent, certain concentrations of functionalized CNTs were add to cocultured with the cells.

\subsubsection{Cell proliferation}

Logarithmic growth phase of three kinds of cells were seeded in 96 well plates at a density of BRL-3A 3000cells per well, NRK 4000 cells per well and RSC96 2500 cells per well, incubated at $37^{\circ} \mathrm{Cand}$ under $5 \% \mathrm{CO}_{2}$ for 24 h. The functionalized CNTs were diluted in the culture medium immediately before addition to each well at the desired final concentrations $\left(10,50,100,150 \mu \mathrm{g} \mathrm{mL}^{-1}\right)$, and the treatment lasted for $24 \mathrm{~h}, 48 \mathrm{~h}, 72 \mathrm{~h}$ and $96 \mathrm{~h}$. Each concentration was located with three parallel holes, set the control group without CNTs, and set the blank hole. For determining cell viability, the WST-1 assay was used. $10 \mu \mathrm{L}$ of WST-1(at $5 \mathrm{mg} \mathrm{mL}^{-1}$, Nanjing KeyGen Biotech CO., Nanjing, China) working solution was added to each well at a final concentration of $500 \mu \mathrm{g} \mathrm{mL}^{-1}$. After the mixture in each well was incubated for $2.5 \mathrm{~h}$, the absorbance was read with a microplate reader (uQuant, Bio-Tek Services, Inc., Richmond, VA) at $450 \mathrm{~nm}$ wavelength. The relative cell viability was expressed as a percentage of the control well that was not treated with functionalized CNTs. The inhibition rate was calculated by the formula: cell inhibition rate $=[1$-absorbance of experimental group/control group absorbance] $\times 100 \%$.

\subsubsection{Cell apoptosis}

Logarithmic growth phase of cells were seeded in 6 well plates at a density of $10^{5} \mathrm{~mL}^{-1}$, incubated at $37^{0} \mathrm{C}$ and under $5 \% \mathrm{CO}_{2}$ for $24 \mathrm{~h}$. After treatment with or without 250 functionalized CNTs for $48 \mathrm{~h}$, at the concentration of 100 and $150 \mu \mathrm{g} \mathrm{mL}^{-1}$, cells were harvested by trypsinization and washed once with phosphate-buffered saline (PBS, $\mathrm{pH}$ 7.4). After centrifugation, the cells were resuspended by $100 \mu \mathrm{L}$ Binding Buffer, and then stained with FITCAnnexin V and Propidium Iodide (Invitrogen) for analysis of cell apoptosis. After a reaction under dark condition for $10 \mathrm{~min}$, the cells were added $400 \mu \mathrm{L}$ Binding Buffer, and then analyzed using a flow cytometer(Model BD LSR II, BD Bioscience, San Jose,CA), channel selection FL1 and FL2.

\subsection{Toxicity in vivo}

40 clean grade SD rats were purchased by the Xinhua Hospital Research Center animal room. When the rats were fed a week in the animal center, they were randomly divided into 3 groups: the control group 16, MWCNT group 12, SWCNT group 12. Then SWCNT and MWCNT groups were divided into four experimental groups $(3,7,14,28$ days experiment group), with three rats per group. At the $1 \mathrm{st}, 14 \mathrm{th}, 21 \mathrm{st}$ and 25 th day, the CNTs dispersion were injected into the tail vein, at a dose of $5 \mathrm{mg} / \mathrm{kg}$, while two mice of the control group were injected the same dose of saline each time. The CNTs dispersion were blended by ultrasonic processor(KQ500DE, Shuzhou, China)with $5 \mathrm{~min}$ before injection Finally at the 28st day, all the rats were anesthesiaed with ketamine, then taken the heart blood $5 \mathrm{~mL}$, with $1.5 \mathrm{~mL}$ for the normal blood test and $3.5 \mathrm{~mL}$ for the detection of liver, kidney function and enzymes (blood parameters were obtained from the Xinhua hospital laboratory). After blood collection, we separated the rat heart, liver, kidney and fixed them in $10 \%$ formalin, preparing pathological section by the pathology department.

\subsection{Statistics}

All values are expressed as mean \pm standard deviation (S.D.). The one-way analysis of variance (one-way ANOVA), followed by Dunnett's multiple comparison post test, was used to verify the significance of a positive response. AP value $<0.05$ was considered statistically significant. Statistical analysis was performed with SPSS18.0.

\section{Results}

\subsection{Toxicity in vitro}

\subsubsection{Cell morphology}

We observe the cell morphology and take pictures with a digital camera, showed in Fig.1. Compared with the control group, there is no significant difference at the four time points in the low-dose groups $\left(10-100 \mu \mathrm{g} \mathrm{mL}^{-1}\right)$. But the high-dose group $\left(150 \mu \mathrm{g} \mathrm{mL}^{-1}\right)$ shows some differences with the control group. At the $24 \mathrm{~h}$ and $48 \mathrm{~h}$ points, there is no difference in number and cell morphology, but when 


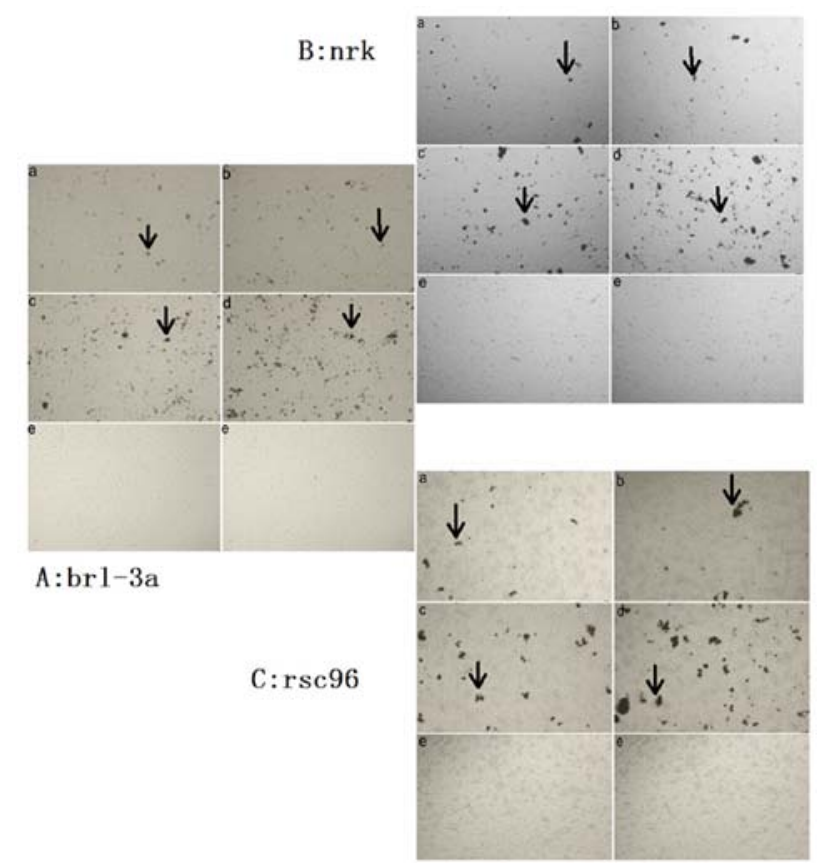

Fig. 1 Functionalized CNTs were co-cultured with three kinds of cell: $\mathrm{A}$ and $\mathrm{C}$ are MWCNT, B is SWCNT. The a, b, c, d and e respectively shows $10,50,100$ and $150 \mu \mathrm{g} \mathrm{ml}^{-1}$ group and the control group means the reunion of the CNTs.

time comes to the $72 \mathrm{~h}$ and $96 \mathrm{~h}$, cells in the experimental group round and shrink, intercellular gap widened, and the number of cell decrease.

\subsubsection{Cell proliferation}

We measure the absorbance (OD) value and analyze statistically (Fig.2). Similar to the cell morphology result, there is a dose-and-time-dependent phenomenon. The results show that there is no significant difference between the experimental group (dose $10-100 \mu \mathrm{g} \mathrm{mL}^{-1}$ ) and the control group, but at the dose of $150 \mu \mathrm{g} \mathrm{mL}^{-1}$, the experimental group performs some differences with the control group. At the $72 \mathrm{~h}$ point, the inhibition rate is over $50 \%$, and the inhibition rate of three cells is showed in Table 1.

Table 1. The inhibition rate of $150 \mu \mathrm{g} \mathrm{mL}^{-1}$ functionalized CNTs at $72 \mathrm{~h}$.

\begin{tabular}{|c|c|c|c|}
\hline & BRL-3A & NRK & RSC96 \\
\hline SWCNT & $61.4 \%$ & $81.6 \%$ & $56.8 \%$ \\
\hline MWCNT & $64.9 \%$ & $76.7 \%$ & $56.8 \%$ \\
\hline
\end{tabular}

\subsubsection{Cell apoptosis}

Following the cell proliferation observation, we then further determine the effect of functionalized CNTsinduced cell death. As shown in Fig. 3, when we treated three kinds of cells with functionalized CNTs for 72 $\mathrm{h}$, at the concentration of 100 and $150 \mu \mathrm{g} \mathrm{mL} \mathrm{m}^{-1}$, we find that there is no significant difference between the $100 \mu \mathrm{g}$ $\mathrm{mL}^{-1}$ group and the control group, which means that this concentration of the two kinds of functionalized CNTs have no effect on the cell apoptosis. But according to
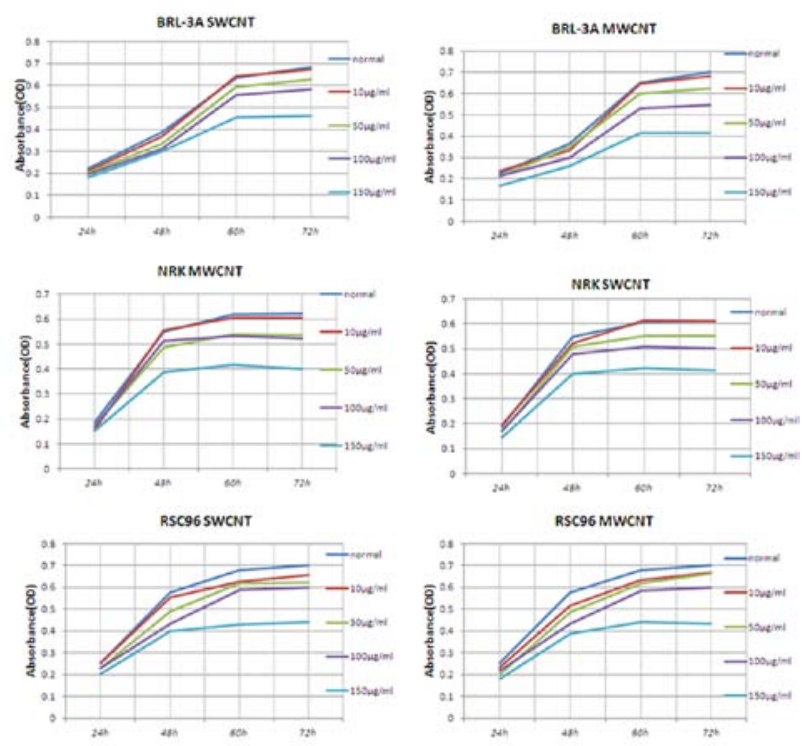

Fig. 2 The effect on cells' proliferation of functionalized CNTs.

the apoptosis data, the concentration of $150 \mu \mathrm{g} \mathrm{mL}^{-1}$ CNTs increases the apoptosis rate significantly, by 10 to 15 percentages. The same to say that $150 \mu \mathrm{g} \mathrm{mL}^{-1}$ of functionalized CNTs significantly promote cell apoptosis (Tab.2).

Table 2. The effect of cell apoptosis rate of functionalized CNTs.

\begin{tabular}{|c|c|c|c|c|}
\hline \multirow{2}{*}{ Item } & \multirow{2}{*}{ CON } & SWCNT & MWCNT & \multirow{2}{*}{$150 \mu \mathrm{gL}^{-1}$} \\
\cline { 3 - 4 } & & $100 \mu \mathrm{g} \mathrm{mL}^{-1}$ & $100 \mu \mathrm{g} \mathrm{mL}^{-1}$ & \\
\hline BRL-3A & $9.2 \%$ & $9.7 \%$ & $9.6 \%$ & $19.6 \%$ \\
\hline NRK & $6.9 \%$ & $7.1 \%$ & $5.8 \%$ & $22.2 \%$ \\
\hline RSC96 & $8.5 \%$ & $9.2 \%$ & $7.7 \%$ & $19.6 \%$ \\
\hline
\end{tabular}

\subsection{The toxicity in vivo}

In heart, We can see focal areas of myocardial atrophy, stained cytoplasm, widened cell gap, infiltration of fat cell is visible in some individual cells gap, changes mainly occurred near the site of the epicardium. In liver, the structural changes are edema and fatty degeneration only in the surrounding areas, the cable structure is clear in central area of liver lobules. There are no blood cells and inflammatory cells, and the morphology of liver cells is normal. In kidney, apocrine secretion increase significantly in the proximal tubules, and the changes focuse in the outer cortex, but renal corpuscles and distal tubules ware normal, with the same to the medullary nephron. In blood, there is no significant change in the number of blood cell and proportion. Among the biochemical parameters, ALT and AST had fluctuations and ultimately returned to normal range. After a slight elevation, BUN and $\mathrm{Cr}$ fell to normal of renal function. Three kinds of enzymes have minor changes, but no significant difference with the normal control group (Fig.4, Tab.3). 


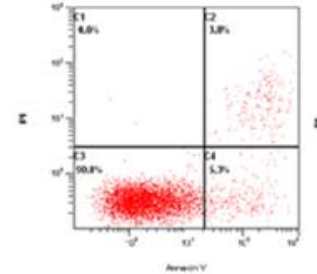

BRL-3A CON

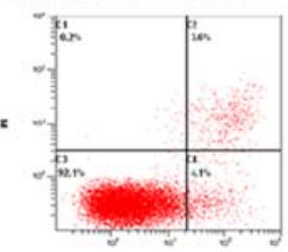

NRK CON

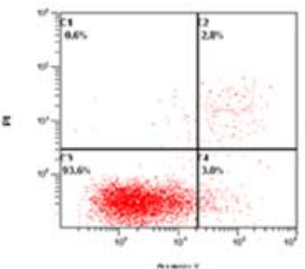

RSC96 CON

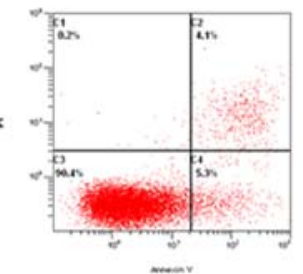

SWCNT(100 $\mu \mathrm{g} / \mathrm{ml})$

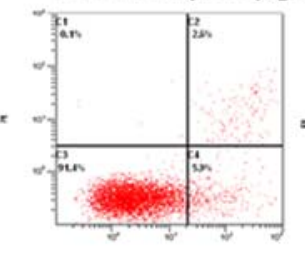

SWCNT(100 $\mu \mathrm{g} / \mathrm{ml})$

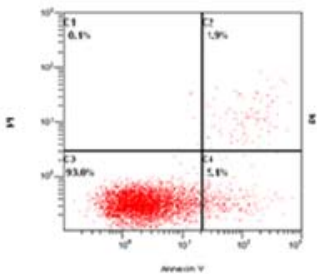

SWCNT $(100 \mu \mathrm{g} / \mathrm{ml})$
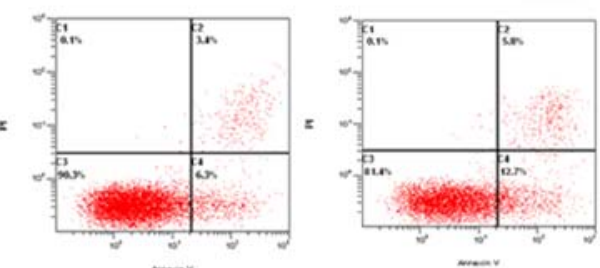

\section{MWCNT(100 $\mu \mathrm{g} / \mathrm{ml}) \quad 150 \mu \mathrm{g} / \mathrm{ml}$}
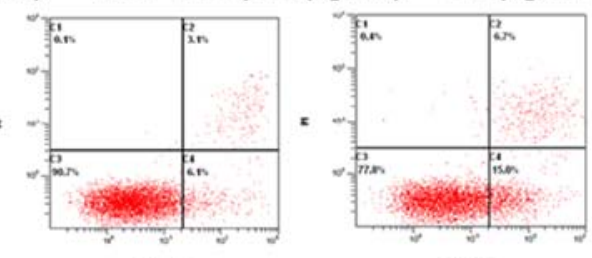

MWCNT(100 $\mu \mathrm{g} / \mathrm{ml}) \quad 150 \mu \mathrm{g} / \mathrm{ml}$
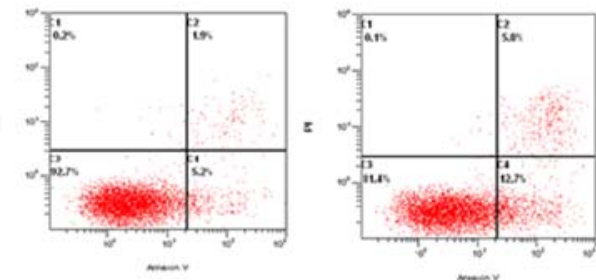

MWCNT(100 $\mu \mathrm{g} / \mathrm{ml})$

$150 \mu \mathrm{g} / \mathrm{ml}$

Fig. 3 The effect of functionalized CNTs on cell apoptosis rate.

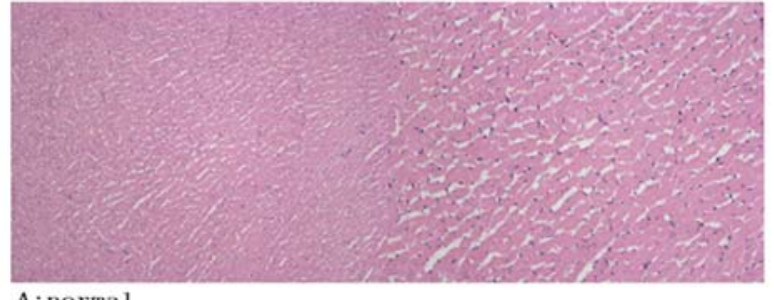

A : norma 1

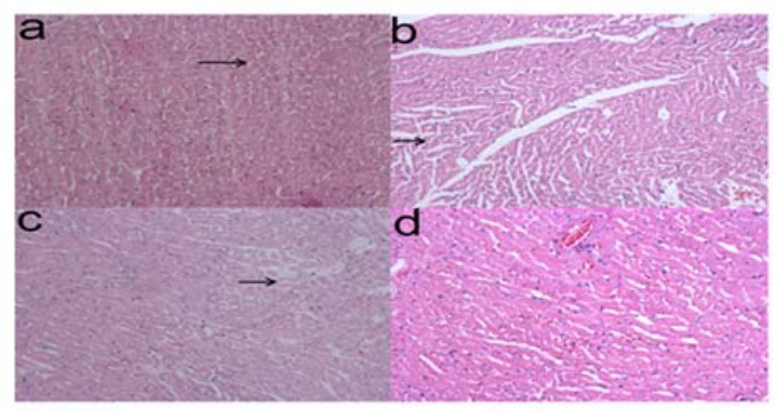

B: mwent

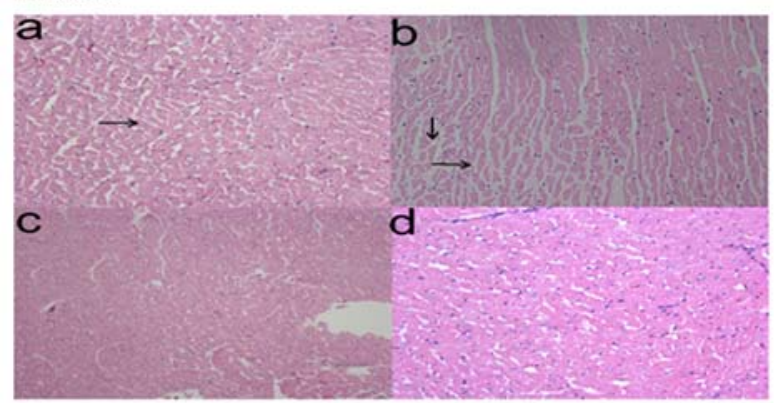

C: swent
Figure 4A: a, b, c and d respectively for the 3rd,7th,14th and 28st day. A : group of normal rat heart, myocardial cell structural is integrity, cytoplasm lightly stained, tightly packed cells, the gap is small. B: MWCNTs injected group, a significant change was only found in the local area, the wider intercellular. b, c some areas there has been myocardial atrophy, cell morphology became round, deeply stained cytoplasm, the cell gap widened significantly, increased over time, but no inflammatory cell infiltration. $\rightarrow$ myocardial contraction. $d$ myocardial cell morphology and structure have become normal myocardium. C: SWCNTs injected group, a, b appeared in some areas of myocardial atrophy, cell morphology became round, deeply stained cytoplasm, the cell gap was widened, and a fat cell infiltration, increased with time, but no infiltration of inflammatory cells into cardiac muscle, $\rightarrow$ atrophy, $\downarrow$ fat cell infiltration. c, d myocardial cell morphology and structure have become normal myocardium.

\section{Discussion}

Generally speaking, the CNT size, degree of aggregation and surface chemical modification is the major factor that impacts the cytotoxicity. Some study showed that SWCNTs had more toxic than MWCNTs [12], mainly because that the diameter of SWCNTs is smaller than that of the MWCNTs, which is more easily to go into cells. In this study, two kinds of functionalized CNTs were co-cultured with three normal cells to watch the cell morphology. We found that the $150 \mu \mathrm{g} \mathrm{mL} \mathrm{m}^{-1}$ group appeared in significant changes in cell morphology, which may be related to the degree of aggregation. In the preparation of CNT suspension, we found that it is difficult to disperse the material. It was easy to 


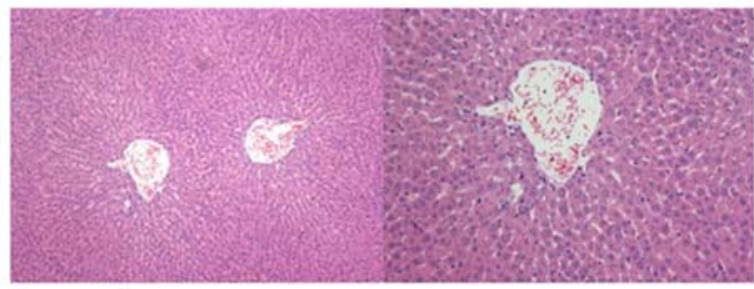

A : norma1

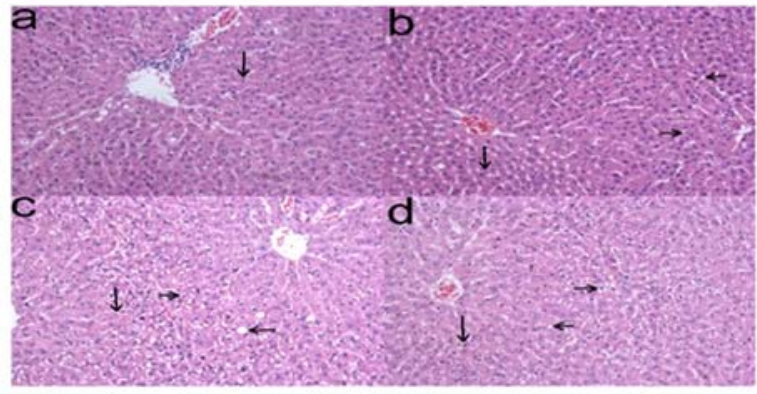

B:mwent

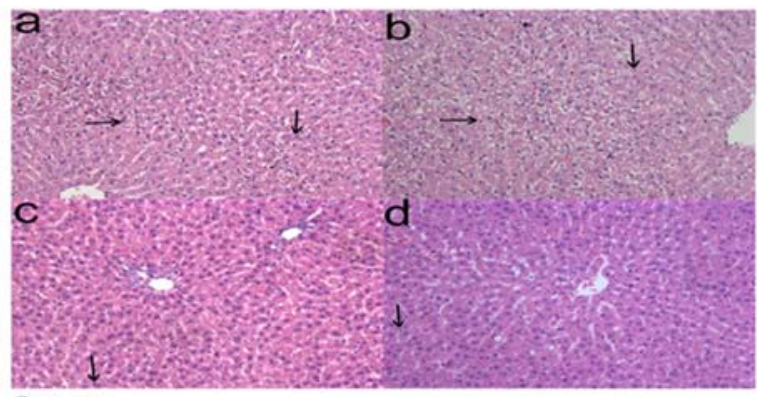

C: swent

Figure 4B: a, b, c and d respectively for the 3rd,7th,14th and 28st day. A: group of normal rat liver, hepatic lobule structure complete, tightly packed, liver cord structure is clear, heparin is no inflammatory cells and blood cells. B: MWCNTs injected group, a significant change was only found that a partial deposition of CNTs or phagocyte. b, c part of the region appeared disordered structure, cell edema and fatty degeneration, the progress of leaflet edge to the center, the deposition of CNTs or phagocyte, increased with time, but no inflammatory cell infiltration; d lobular structure has clearly improved over the previous two groups, but there is still adaptive changes and CNTs deposition, $\rightarrow$ cell edema, $\leftarrow$ fatty degeneration, $\downarrow$ CNTs deposition. C: SWVNTs injected group, $\mathrm{a}, \mathrm{b}$ some areas there has changes in the structure of hepatic lobule, the progress from the edge to the center of lobules, changes of cell edema and deposition of CNTs or phagocyte, increased with time, but no inflammatory cell infiltration, $\rightarrow$ cell edema, $\leftarrow$ fatty degeneration, $\downarrow$ CNTs deposition. c, $d$ liver cell morphology and structure have become normal hepatic lobule, CNTs deposition is still there, $\downarrow$ CNTs deposition

agglomerate, so we had to use ultrasound to disperse the material prior. Wick et al [13] examined the different degree of aggregation of SWCNTs on human MSTO$211 \mathrm{H}$ cell toxicity and found that a large gathering can induce greater hardness and size, and thus have greater toxicity. The difference with previous reports [14] is that between the SWCNTs and MWCNTs we didn't find differences in the impact of cell morphology.

MTT assay is a commonly used cell number and viability detection methods, but studies have shown, the formazan particle, generated in the MTT procession, was easily absorbed to CNTs surface, and transmission electron microscopy showed that the formazan-CNTs combination was not easy to be dissolved by DMSO, which decreased Nano Biomed. Eng. 2011, 3(4), 249-255

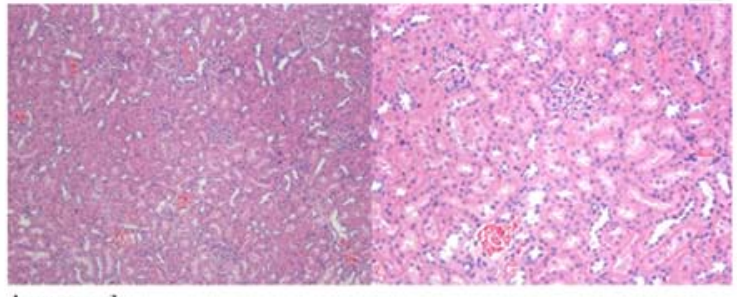

A : norma 1

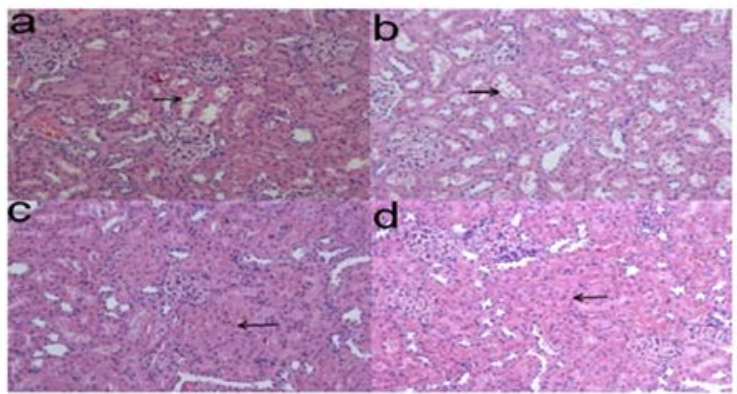

B:mwent

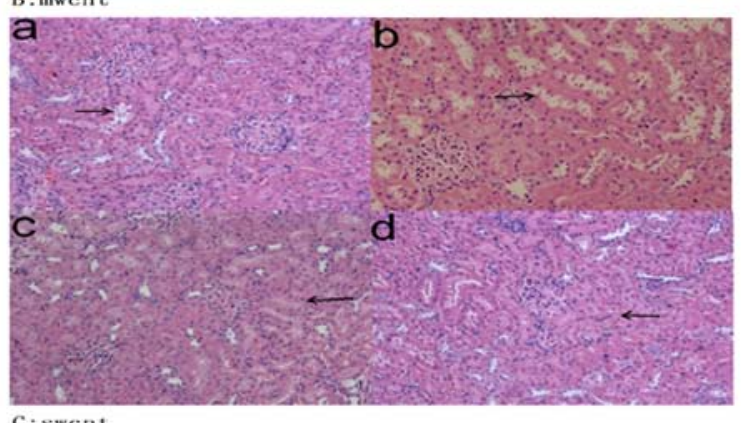

C:swent

Fig. 4C: a, b, c and d respectively for the 3rd,7th,14th and 28st day. A: group of normal rat kidney, renal unit structural integrity, deeply stained proximal tubule, distal tubule lightly stained. B: MWCNTs injected group, a, b in the proximal tubules of apocrine secretion increased, increased with time, $\rightarrow$ apocrine secretion. c, d proximal tubule of apocrine secretion is normal, but some areas there has been tightly packed proximal tubule phenomenon, $\leftarrow$ packed proximal tubule. C: SWCNTs injected group, a, b in proximal tubule apocrine secretion increased, reduced with time, $\rightarrow$ apocrine secretion. c, d proximal tubules of apocrine secretion is normal, but some areas there has been the phenomenon of the proximal tubules tightly packed, reduced with time.

the absorption caused false-positive results [15].But, in the WST-1 experiment, such phenomenon wound not appear. WST-1 is a more sensitive, more stable compounds, similar to MTT, the electron coupling reagent in the presence of, can be reduced to water-soluble formazan by some dehydrogenase in the mitochondria, which can be dissolved in tissue culture medium. The amount proportional depended on the amount of cells. WST-1 results showed that the functionalized CNTs have a certain concentration range of security on the three kinds of normal rat cell, beyond this range would show cytotoxicity. And they showed greater toxicity in the kidney cells.

The two kinds of materials caused different pathological changes. In the liver, SWCNTs caused cell edema, and the changes induced by MWCNTs were edema and part of the fatty degeneration, occurred in 
http://nanobe.org

Table 3A. The changes of blood parameters by MWCNTs

\begin{tabular}{|c|c|c|c|c|c|c|}
\hline Item & Normal & 1 day & 3 day & 7 day & 14 day & 28 day \\
\hline $\operatorname{WBC}\left(10^{9} \mathrm{~L}^{-1}\right)$ & $3.76 \pm 1.18$ & $3.91 \pm 1.25$ & $5.28 \pm 2.36$ & $4.94 \pm 1.24$ & $2.6 \pm 1.05$ & $3.09 \pm 1.89$ \\
\hline $\operatorname{RBC}\left(10^{12} \mathrm{~L}^{-1}\right)$ & $8.12 \pm 0.76$ & $8.18 \pm 0.74$ & $7.58 \pm 0.67$ & $7.86 \pm 0.71$ & $7.33 \pm 0.53$ & $8.43 \pm 0.84$ \\
\hline $\mathrm{HB}\left(\mathrm{g} \mathrm{L}^{-1}\right)$ & $147 \pm 15$ & $154 \pm 13$ & $183 \pm 27$ & $205 \pm 26$ & $146 \pm 10$ & $165 \pm 18$ \\
\hline $\mathrm{BPC}\left(10^{9} \mathrm{~L}^{-1}\right)$ & $1132 \pm 111$ & $1427 \pm 123$ & $1675 \pm 180$ & $1361 \pm 141$ & $1131 \pm 123$ & $1298 \pm 195$ \\
\hline $\mathrm{N}(\%)$ & $16.7 \pm 2.4$ & $29.7 \pm 4.1$ & $25.9 \pm 3.8$ & $17.4 \pm 2.7$ & $13.1 \pm 2.2$ & $18.7 \pm 2.6$ \\
\hline $\mathrm{L}(\%)$ & $79.3 \pm 5.5$ & $54.2 \pm 4.5$ & $66.5 \pm 4.8$ & $74.9 \pm 5.1$ & $78.8 \pm 5.8$ & $69.7 \pm 5.1$ \\
\hline $\operatorname{ALT}\left(\mathrm{u} \mathrm{L}^{-1}\right)$ & $28 \pm 6.49$ & $37 \pm 8.41$ & $40 \pm 7.54$ & $47 \pm 8.19$ & $44 \pm 7.08$ & $28 \pm 6.56$ \\
\hline $\operatorname{AST}\left(u L^{-1}\right)$ & $91 \pm 26.54$ & $89 \pm 26.75$ & $101 \pm 29.14$ & $117 \pm 32.74$ & $87 \pm 25.47$ & $78 \pm 21.89$ \\
\hline $\mathrm{TP}\left(\mathrm{g} \mathrm{L}^{-1}\right)$ & $61 \pm 4.6$ & $72.1 \pm 5.1$ & $62.9 \pm 4.9$ & $65.8 \pm 5.4$ & $65.2 \pm 5.8$ & $60.8 \pm 4.2$ \\
\hline $\operatorname{ALB}\left(\mathrm{g} \mathrm{L}^{-1}\right)$ & $40.3 \pm 1.96$ & $45 \pm 2.52$ & $40.9 \pm 1.95$ & $42.3 \pm 2.02$ & $41.9 \pm 1.98$ & $42.2 \pm 1.67$ \\
\hline $\mathrm{BUN}\left(\mathrm{mmol} \mathrm{L}^{-1}\right)$ & $5.79 \pm 1.22$ & $7.99 \pm 2.6$ & $9.25 \pm 2.39$ & $9.97 \pm 1.98$ & $8.12 \pm 2.17$ & $7.15 \pm 2.25$ \\
\hline $\mathrm{CR}\left(\mu \mathrm{mol} \mathrm{L}{ }^{-1}\right)$ & $31 \pm 8.3$ & $39 \pm 9.6$ & $46 \pm 13.7$ & $38 \pm 10.7$ & $36 \pm 5.7$ & $30 \pm 6.7$ \\
\hline CK-MB $\left(\mathrm{u} \mathrm{L}^{-1}\right)$ & $323 \pm 21.4$ & $526 \pm 94.6$ & $649 \pm 132.7$ & $540 \pm 90.3$ & $426 \pm 75.9$ & $386 \pm 50.1$ \\
\hline $\operatorname{HBDH}\left(\mathrm{u} \mathrm{L}^{-1}\right)$ & $207 \pm 24.5$ & $291 \pm 43.6$ & $349 \pm 49.5$ & $280 \pm 35.7$ & $274 \pm 30.5$ & $242 \pm 26.3$ \\
\hline $\mathrm{LDH}\left(\mathrm{u} \mathrm{L}^{-1}\right)$ & $278 \pm 21.8$ & $486 \pm 70.6$ & $417 \pm 57.6$ & $365 \pm 50.3$ & $263 \pm 27.7$ & $225 \pm 20.4$ \\
\hline
\end{tabular}

Table 3B. The changes of blood parameters by SWCNTs

\begin{tabular}{|c|c|c|c|c|c|c|}
\hline Item & Normal & 1 day & 3 day & 7 day & 14 day & 28 day \\
\hline $\mathrm{WBC}\left(10^{9} \mathrm{~L}^{-1}\right)$ & $3.76 \pm 1.18$ & $4.95 \pm 2.28$ & $5.51 \pm 1.96$ & $5.55 \pm 1.96$ & $5.42 \pm 2.39$ & $3.57 \pm 2.43$ \\
\hline $\operatorname{RBC}\left(10^{12} \mathrm{~L}^{-1}\right)$ & $8.12 \pm 0.76$ & $8.27 \pm 0.78$ & $7.32 \pm 0.65$ & $7.39 \pm 0.67$ & $8.11 \pm 0.75$ & $8.71 \pm 0.84$ \\
\hline $\mathrm{HB}\left(\mathrm{g} \mathrm{L}^{-1}\right)$ & $147 \pm 15$ & $152 \pm 17$ & $142 \pm 14$ & $138 \pm 12$ & $149 \pm 18$ & $175 \pm 21$ \\
\hline $\operatorname{BPC}\left(10^{9} \mathrm{~L}^{-1}\right)$ & $1132 \pm 111$ & $1345 \pm 142$ & $1461 \pm 183$ & $1361 \pm 194$ & $1040 \pm 107$ & $1289 \pm 167$ \\
\hline $\mathrm{N}(\%)$ & $16.7 \pm 2.4$ & $22.6 \pm 2.9$ & $27.7 \pm 3.6$ & $12.6 \pm 2.2$ & $10.1 \pm 2.1$ & $16.3 \pm 1.6$ \\
\hline $\mathrm{L}(\%)$ & $79.3 \pm 5.5$ & $67.7 \pm 5.2$ & $65.2 \pm 4.9$ & $81.2 \pm 5.7$ & $80.6 \pm 5.6$ & $81.2 \pm 5.8$ \\
\hline $\operatorname{ALT}\left(\mathrm{u} \mathrm{L}^{-1}\right)$ & $28 \pm 6.49$ & $38 \pm 6.91$ & $36 \pm 6.84$ & $25 \pm 6.79$ & $23 \pm 5.67$ & $29 \pm 7.89$ \\
\hline $\operatorname{AST}\left(\mathrm{u} \mathrm{L}^{-1}\right)$ & $91 \pm 26.54$ & $107 \pm 27$ & $114 \pm 30$ & $88 \pm 22$ & $83 \pm 21$ & $95 \pm 30$ \\
\hline $\mathrm{TP}\left(\mathrm{g} \mathrm{L}^{-1}\right)$ & $61 \pm 4.63$ & $61.3 \pm 467$ & $64.5 \pm 4.72$ & $66.3 \pm 4.89$ & $70.1 \pm 5.33$ & $61.1 \pm 4.64$ \\
\hline $\operatorname{ALB}\left(\mathrm{g} \mathrm{L}^{-1}\right)$ & $40.3 \pm 1.96$ & $38.9 \pm 1.92$ & $41.4 \pm 2.01$ & $43 \pm 2.34$ & $46.7 \pm 2.47$ & $34.6 \pm 1.75$ \\
\hline $\mathrm{BUN}\left(\mathrm{mmol} \mathrm{L}^{-1}\right)$ & $5.79 \pm 1.22$ & $6.55 \pm 1.45$ & $7.11 \pm 1.56$ & $6.45 \pm 1.59$ & $5.77 \pm 1.35$ & $5.42 \pm 1.27$ \\
\hline $\mathrm{CR}\left(\mu \mathrm{mol} \mathrm{L}{ }^{-1}\right)$ & $31 \pm 8.3$ & $45 \pm 10.3$ & $39 \pm 8.5$ & $33 \pm 8.4$ & $36 \pm 9.1$ & $28 \pm 7.5$ \\
\hline $\mathrm{CK}-\mathrm{MB}\left(\mathrm{u} \mathrm{L}^{-1}\right)$ & $323 \pm 21.4$ & $532 \pm 90.4$ & $431 \pm 56.3$ & $287 \pm 40.7$ & $293 \pm 45.2$ & $359 \pm 36.8$ \\
\hline $\operatorname{HBDH}\left(\mathrm{u} \mathrm{L}^{-1}\right)$ & $207 \pm 24.5$ & $329 \pm 50.5$ & $328 \pm 58.3$ & $259 \pm 37.4$ & $199 \pm 32.4$ & $198 \pm 16.5$ \\
\hline $\mathrm{LDH}\left(\mathrm{u} \mathrm{L}^{-1}\right)$ & $278 \pm 21.8$ & $482 \pm 62.6$ & $360 \pm 53.6$ & $288 \pm 30.5$ & $244 \pm 26.6$ & $272 \pm 14.6$ \\
\hline
\end{tabular}

the lobular edge position. In the three tissues, MWCNTs induced changes mainly in the middle and late stage, while SWCNTs mainly in the early period, which seemed to say that the MWCNTs showed more pathological efficacy. Accompanied by organizational changes, the relevant blood parameters had some volatility, but there was no difference between the two kinds of CNTs. Every experimental group didn't find significant inflammatory cell infiltration. After intravenous injection of CNTs, each 254 experimental group of mice didn't perform any serious pathological changes, such as apoptosis, necrosis. The result demonstrated that the tissue had a certain self-repair capacity to treat the adaptive changes in the body.

Whether surface modification of CNTs shows some cytotoxic effect, the current experiment studies still have some controversy. Bottini et al [16] compared the original with the carboxylic MWCNTs by nitric acid, found that 
oxidation of the CNTs showed higher toxicity. But Kam et al [17] reported that nitric acid oxidized SWCNTs cocultured with human HL60 promyelocytic leukemia cells at the concentration of $50 \mu \mathrm{g} \mathrm{mL}^{-1}$, after 24 and $48 \mathrm{~h}$ there showed no cell death, indicating that the functionalized SWCNTs had no toxic effect on HL60 cells. Sayes et al [18] found that acid-modified and isophthalic acidmodified SWCNTs showed smaller toxicity than the original material on human dermal fibroblasts, pointed that cell toxicity depended on functional density, the higher functional density, the smaller cytotoxicity. The original SWCNTs were more toxic than the SWCNTs removed metal impurities [19]. In summary, modifying the surface of the CNTs will show better biocompatibility [20]. Rare earth elements have the feature of low electronegative and large activity, which can be used as surfactants and shallow infiltration of elements [21], because of the typical electronic structure (- - 4f0-14). If we use the rare earth elements to function the surface of CNTs, they can clean the surface of the CNTs, and reduce the surface energy, to be better biocompatibility and more easily dispersed.

The functionalized MWCNTs and SWCNTs have good biocompatibility at lower concentrations, the functionalized SWCNTs perform in the early period in the animal body and MWCNTs mainly in the late, which show a more serious toxicity. Oxidative stress is one of the mechanisms leading to cell toxicity of CNTs, but different chemical surface properties of CNTs may have a different mechanism on cell viability, the mechanism needs further study, and its preparation process also needs further study and improvement. Cells and tissues have the capacity of adaptability and self-repair mechanisms to balance the damage caused by functionalized CNTs, the activity of cells and tissues gradually restored with time, speculating that the removal of cells ROS is one of the reasons, but the specific clearance mechanism has yet needs future study.

\section{Acknowledgements}

The authors gratefully acknowledge Lishun WANG PH.D., Key Laboratory of Cell Differentiation and Apoptosis of National Ministry of Education. This study was supported by the grant from the National Natural Science Fundation (Project No. 81102016).

\section{References}

1. Bonard JM, Kind H, Stockli T, Nilsson LO. Field emission from carbon nanotubes: The first five years.Solid State Electron. 2001;45:893-914.http://dx.doi.org/10.1016/S0038-1101(00)00213-6

2. Baughman RH, Zakhidov AA, de Heer WA. Carbon nanotubes-the route toward applications.Science.2002;297:787-792. http://dx.doi.org/10.1126/science. 1060928

3. Avouris PH. Carbon nanotube electronics. Chem Phys. 2002;281:
429.http://dx.doi.org/10.1016/S0301-0104(02)00376-2

4. Iijima S. Helical microtubules of graphitic carbon. Nature. 1991; 354:56-58.http://dx.doi.org/10.1038/354056a0

5. Bachtold A, Fuhrer MS, Plyasunov S. Scanned probe microscopy of electronic transport in carbon nanotubes. Phys Rev Lett. 2000;84 (26 Pt 1):6082-6085.http://dx.doi.org/10.1103/PhysRevLett.84.6082

6. McEuen PL, Fuhrer MS, Park H. Single-walled carbon nanotube electronics. IEEE Trans Nanotech. 2002;1:78-185.

7. Durkop T, Getty SA, Cobas E, Fuhrer MS. Extraordinary mobility in semiconducting carbon nanotubes. Nano Lett.2004;4:35-39. http://dx.doi.org/10.1021/n1034841q

8. Bachilo SM, Strano MS, Kittrell C. Structure-assigned optical spectra of single-walled carbon nanotubes. Science. 2002;298:2361-2366. http://dx.doi.org/10.1126/science.1078727

9. Zhang Z, Yang X, Zhang Y. Delivery of telomerase reverse transcriptase small interfering RNA in complex with positively charged single-walled nanotubes suppresses tumor growth. Clin Cancer Res. 2006;12:4933-4939.http://dx.doi.org/10.1158/10780432.CCR-05-2831

10.Kam NW, O'Connell M, Wisdom JA, Dai H. Carbon nanotubes as multifunctional biological transporters and nearinfrared agents for selective cancer cell destruction. Proc Natl Acad Sci USA. 2005;102:11600-11605.http://dx.doi.org/10.1073/pnas.0502680102

11.Kam NW, Liu Z, Dai H. Functionalization of carbon nanotubes via cleavable disulfide bonds for efficient intracellular delivery of siRNA and potent gene silencing. $J$ Am Chem Soc. 2005;127:1249212493.http://dx.doi.org/10.1021/ja053962k

12.Jia G, Wang H, Yan L, et al. Cytotoxicity of carbon nanomaterials: single-wall nanotube, multi-wall nanotube, and fullerene. Environ Sci Technol.2005;39(5):1378-1383.http://dx.doi.org/10.1021/ es 0487291

13. Wick P, Manser P, Limbach LK, et al. The degree and kind of agglomeration affect carbon nanotube cytotoxicity. Toxicol Lett. 2007;168 (2):121-131.http://dx.doi.org/10.1016/j.toxlet.2006.08.019

14.Wang B, Feng WY, Zhao LY, et al. Research of biological and toxicological effects of nanomaterials. Science in China Ser. B Chemistry.2004;35:1-9.

15.Wörle-Knirsch JM, Pulskamp K, Krug HF. Oops they did it again! Carbon nanotubes hoax scientists in viability assays. Nano Lett. 2006;6 (6):1261-1268.http://dx.doi.org/10.1021/n1060177c

16.Bottini M, Bruckner S, Nika K, et al. Multi-walled carbon nanotubes induce T lymphocyte apoptosis. Toxicol Lett. 2006;160 (2):121126.http://dx.doi.org/10.1016/j.toxlet.2005.06.020

17.Kam NW, Dai H. Carbon nanotubes as intracellular protein transporters: generality and biological functionality.J $\mathrm{Am}$ Chem Soc. 2005;127(16):6021-6026.http://dx.doi.org/10.1021/ja050062v

18.Sayes CM, Liang F, Hudson JL, et al. Functionalization density dependence of single-walled carbon nanotubes cytotoxicity in vitro.Toxicol Lett. 2006;161 (2):135-142.http://dx.doi.org/10.1016/ j.toxlet.2005.08.011

19. Tian F, Cui D, Schwarz H, et al. Cytotoxicity of single-wall carbon nanotubes on human fibroblasts. Toxicol In Vitro. 2006; 20(7): 1202-1212.http://dx.doi.org/10.1016/j.tiv.2006.03.008

20.Wang Y, Lin Q, Wu K, et al. Experimental study on cells biological safety of single-wall and multi-wall carbon nanotubes. Chin J Exp Surg.2012.In press.

21 Bai T, Cheng XH. Nano-tribological characteristics of lanthanum-based thin films on sulfonated self-assembled monolayer of 3-mercaptopropyl trimethoxysilane. Journal of Rare Earths.2008;26(1):93-98.http://dx.doi.org/10.1016/S1002-/ 0721(08)60045-9

Copyright:(c) 2011 Y. Wang, et al. This is an open-access article distributed under the terms of the Creative Commons Attribution License, which permits unrestricted use, distribution, and reproduction in any medium, provided the original author and source are credited. 